\title{
Satya - Svasthya Ayurveda Treatment Yoga and Agriculture
}

\section{Anita Mani ${ }^{1-3^{*}}$}

${ }^{1}$ Infertility Specialist \& Laparoscopic Surgeon, Director - Gift Gyno IVF Hospital, India

${ }^{2}$ Royal Infirmary, Maidstone Hospital, UK

${ }^{3}$ Leeds university Hospital, Barnet, Genera, UK

"Corresponding author: Anita Mani, Leeds university Hospital, Barnet, Genera, UK, Tel: +919446475033; E-mail:anitadane@gmail.com

Received date: April 20, 2017, Accepted date: April 25, 2017, Published date: April 28, 2017

Copyright: (c) 2017 Mani A. This is an open-access article distributed under the terms of the Creative Commons Attribution License, which permits unrestricted use, distribution, and reproduction in any medium, provided the original author and source are credited.

\begin{abstract}
Pollution of the environment is a serious health concern faced by humanity which needs immediate tackling to protect our future generations. It is not an issue which should be left only to the Government or Environmentalists to deal with, each one of us have a responsibility to do our part. This health hazard is exacerbated by the fact that we are going away from nature's ways which is leading to life threatening diseases and unhealthy body. The new generation is so engrossed in social media that they are losing touch with the surroundings and themselves. Satya is a bold step towards addressing this problem and strives to bring people closer to nature and in the process bringing about self-realization and self-healing.
\end{abstract}

Keywords: Health concern; Ayurveda treatment; Yoga; Satya

\section{Introduction}

In the contemporary scenario we are wrapped up in luxury, but nature's simple and elegant bounties are but a distant dream. "SATYA Svasthya Ayurveda treatment Yoga \& Agriculture" is found to accomplish this vision. Close to the lively town, away from the rush, this haven is situated at Athani, near Cochin International Airport Junction. Satya was created with a broad perspective to provide a holistic treatment for spiritual and physical health, to give a chance to artists to display their talent and ability, to bring together the environmentalists, for creating awareness about the importance of protecting the greenery as well as planting more trees.

Meaning of Satya translates into "Truth and honesty". But in a wider sense it has a deeper meaning. We have to live in synchronization with nature and truth, which will ensure peace of mind and contentment and this in turn will keep us in pink of health. If you are true to your own self you will find gratification and happiness. Only a sound mind can give you a healthy body. Ayurveda and yoga [1-3] have a strong connection and together can work miracles in healing.

SATYA provide holistic cure with a combination of Ayurveda, naturopathy [4], farming, music therapy, Yoga and meditation. Bamboo beauty spa which is a part of Satya offers relaxing and rejuvenating massages, hair and beauty treatments.

This project is a comprehensive wellness center of superior standards and aims to provide a platform for the artists to showcase their talent, to give a farming experience to the new generation and to raise awareness for a cause we firmly believe in (planting more trees to save nature is our motto). We have planned space for art exhibitions, painting camps, yoga camps and a charity shop for plantation of trees. At Satya, you will find an eclectic fusion of rich ayurvedic history and modern comfort.

'Let food be thy medicine and medicine be thy food.' These wise words spoken centuries back by Hippocrates are very relevant today.
Most of the people are leading an unhealthy lifestyle eating unhealthy food which is the root cause of many diseases and aches. Rather than following a healthy way of life which could keep their bodies healthy, they prefer to wait for the ailment to strike and then run to get medical help.

We have an obligation towards our body; please do not overload the system with pesticide laden food and junk food that is difficult to digest. Be kind to your digestive system. Paying slight attention to what you eat can go a long way in keeping you in good physical shape.

Many of the diseases like Cancer, diabetes, cardiac troubles, pulmonary issues, allergies, hypertension [5] were uncommon and found only among a few before, but these conditions have become rampant now. We need to find the root of these problems and uproot them so as to avoid a sick and unhealthy future generation.

External influences like pollution is beyond control, so let us at least do what we can. Nature has endowed us with nutritious produce, let us try not to poison these gifts with pesticides and manipulate it with genetic modifications. Organic farming should to be more extensive and widely prevalent. At Satya, there is an organic garden and farm which houses many exotic fruit trees, vegetable plants, birds and animals.

The soil is the great connector of lives; it is the healer and restorer, by which disease passes into health, age into youth and death into life. I do the farming for the passion of farming.

I find peace and solace when surrounded by plants trees and animals, I relish toiling in the open air, taking delight in the weather absorbing the vitamin D from the sunlight. Vitamin D deficiency [6,7] is so rampant now days for the simple reason being that we do not get enough sunlight on our body.

Agriculture is considered to the noblest of all vocation, but sadly farmers don't get their due even though they toil hard to feed the society. It is not an impossible or laborious task to cultivate a tiny organic garden with herbs and vegetables at your place and the outcome is not only healthy but very rewarding. We have a 
Citation: Mani A (2017) Satya - Svasthya Ayurveda Treatment Yoga and Agriculture. J Gen Pract (Los Angel) 5: 306. doi: 10.4172/2329-9126.1000306

Page 2 of 2

responsibility towards our future generation, plant more trees, and go green. Spending time with nature and breathing fresh air can be a great idea to rejuvenate and heal your body and mind.

\section{Conclusion}

Along with healthy food, physical activity is a must for healthy living, at Satya, there are classes for Barathanatyam, kalarippayattu, weight cut back program at the fitness center

"All that man needs for health and healing has been provided by God in nature, the Challenge of science is to find it." Paracelsus was wise enough to give such a statement in 15th century and we living in 21 st century are still foolish not to accept this fact.

\section{References}

1. Chopra A, Doiphode VV (2002) Ayurvedic medicine: Core concept, therapeutic principles, and current relevance. Med Clin North Am 86: 75-89.
2. Ross S, Thomas S (2010) The health benefits of yoga and exercise: A review of comparison studies. J Altern Complement Med 16: 3-12.

3. Birdee GS,. Ayala SG, Wallston KA (2017) Cross-sectional analysis of health-related quality of life and elements of yoga practice. BMC Complement Altern Med 17:83.

4. Sathyaprabha TN, Murthy H, Murthy BT (2001) Efficacy of naturopathy and yoga in bronchial asthma, a self-controlled matched scientific study. Indian J Phyaiol Pharmacol 45: 80-86.

5. Lin CD, Silvestro M, Migliorini R, Tona F, Fioranelli M (2017) Integrated Approach to Hypertension. 185-201.

6. Loomis WF (1970) Although it is still widely regarded as a dietarydeficiency disease resulting from a lack of "vitamin D," it results in fact from a lack of sunlight. In smoky cities it was the first air-pollution disease. Sci Am 8:77.

7. Webb AR, Kline L, Holick MF (1988) Influence of season and latitude on the cutaneous synthesis of vitamin D3: Exposure to winter sunlight in Boston and Edmonton will not promote vitamin D3 synthesis in human skin. J Clin Endocrinol Metab 67: 373-378. 